\title{
Articles
}

\section{Information literacy and the Workforce: A Review}

By Sharon Weiner

\begin{abstract}
This paper is a review of reports on information literacy and the workforce. There is a substantial body of literature on information literacy in K-16 educational settings, but there is much less literature on implications for the workplace and job-related lifelong learning. The topical categories of the reports are: the importance of information literacy for the workforce; how information literacy differs in work and educational settings; and barriers to information literacy in the workplace. The paper concludes with recommendations for practice and for further research.
\end{abstract}

\section{Introduction}

Recent reports from industry and the literature indicate that information literacy and the related competencies, critical thinking and lifelong learning, are very important to employers. There is a growing consensus on the need for an information literate workforce and sense of urgency about its implementation (American Management Association, 2010; Zhang, 2010; Achieve, 2008; Perrault, 2007; Peter D. Hart Research, 2005; Goad, 2002; Partnership for $21^{\text {st }}$ Century Skills). The Association for College and Research Libraries described an information literate person as one who has the ability to:

- "Determine the extent of information needed

- Access the needed information effectively and efficiently

- Evaluate information and its sources critically

- Incorporate selected information into one's knowledge base

- Use information effectively to accomplish a specific purpose

- Understand the economic, legal, and social issues surrounding the use of information, and access and use information ethically and legally" (ACRL, 2000)

Beyond the acquisition of skills, information literacy "is an all encompassing process by which one interacts with information in diverse formats and is complemented by the transformative effect of this experience. By this definition information literacy is the foundation of lifelong learning because it promotes a multifaceted literacy supported by critical and reflective learning" (Andretta, 2007. p. 12). There is an association between these skills and the ability to be lifelong learners (Cavalieri, 2009).

The field of information literacy has developed considerably since Paul Zurkowski, past President of the Information Industry Association, coined the term in 1974 (Zurkowski, 1974). There are listings of milestones in information literacy in papers published by Weiner, and Weiner and Jackman (Weiner, 2011; Weiner \& Jackman, 2010). A significant link to the workforce occurred in a 1989 consensus statement of prominent information literacy advocates (ACRL, 1989). That led to the formation of the National Forum on Information Literacy (NFIL). The NFIL assumed a role of addressing "all major educational and societal issues connected to information literacy" (Gibson, 2004). Workforce readiness was one of those issues, and was a primary topic for discussion at an Information Literacy Summit sponsored by NFIL (Perrault, 2007). Information literacy and its function in employee training and economic competitiveness gained momentum beyond individual nations when the NFIL, International Federation of Library Associations, and UNESCO co-sponsored two international colloquia. The report of the first colloquium, held in Prague, stated that

Education Libraries, Volume 34, Number 2, Winter 2011 
"information literacy is a fundamental skill in the workplace that produces positive outcomes for small and large businesses alike" (Thompson, 2003). The report of the second colloquium, held in Alexandria, Egypt, stated that "under current globalization trends, economic development is becoming increasingly dependent upon the use of information and the learning skills of the workforce" (Garner, 2006). ETS developed the iSkills ${ }^{\mathrm{TM}}$ Assessment, the first commercially available assessment of critical thinking in undergraduate students and the workforce (http://www.ets.org/iskills/about). These policylevel activities, statements, recommendations and evaluation tool form a foundation for practice and research on information literacy in the workplace.

Although there is a substantial body of literature on information literacy in K-16 educational settings, there is much less literature on its implications for the workplace and job-related lifelong learning (Lloyd, 2010; Lloyd \& Williamson, 2008; Kirton \& Barham, 2005). Further, there is evidence that the ways in which information literacy skills are taught to students do not result in effective application in the workplace (O'Farrill, 2010; Lloyd, 2003). Lloyd reviewed the research on workplace information literacy particularly from the Australian and U.K. perspectives. She described the work of Bruce, Cheuk, and Lloyd as foundational in this area. She examined issues that emerged in the literature related to the terminology of information literacy; its role with small-to-medium-sized businesses; and the need for advocacy for information literacy in the workplace (Lloyd, 2010). Lloyd concluded that the information literacy skills-based paradigm that is prevalent in the educational sector exists in the workplace, too. She posited that a sociocultural approach is more appropriate. This approach is more complex than skills training, and allows for the differing needs and contexts of workplaces (Lloyd, 2010).

This paper is a review of reports from the past decade on information literacy and the workforce. The reports summarized in this paper are organized in these thematic sections: the importance of information literacy for the workforce; how information literacy differs in work and educational settings; and barriers to information literacy in the workplace. The paper concludes with recommendations for practice and for further research drawn from these reports.

\section{Importance of Information Literacy for the Workforce}

The ability to locate, understand, and use information and to solve problems is a necessary competency for most jobs (Goad, 2002; Klusek \& Bornstein, 2006; Gardner, 2000). Success in business and other organizations requires the ability to monitor trends and readily adapt to them. Employers consider information literacy to be important to the workforce because they need a workforce that has the willingness and the ability to continually learn new skills. Employees should be "confident and competent in interacting with information to deliver maximum business value" (Cheuk, 2008). They must be able "to adopt and adapt, create and recreate, contextualize and recontextualize" (Lloyd, 2003). Information literacy is necessary for businesses to be competitive (Perrault, 2007).

The elements of information literacy provide a foundation for the "habits of mind," or ways of thinking, by which employees can engage in these activities. Although not empirically tested, Goad (2002) proposed sixteen steps for information literacy as a process that occurs in the workplace. These steps are:

1. Establish the need.

2. Break the subject down into its parts.

3. Identify the relationships and hierarchies.

4. Identify information sources.

5. Identify multiple sources.

6. Select a strategy.

7. Develop a question list.

8. Conduct the search.

9. Authenticate the information.

10. Filter the information while remaining focused.

11. Analyze the information.

12. Summarize the information once gathered.

13. Select the information that applies. 
14. Put information into context.

15. Apply the information.

16. Evaluate the action taken and reenter as necessary.

The importance of information literacy in all sectors of life is garnering attention at the federal level in the United States. The National Forum on Information Literacy (NFIL) waged a campaign for the White House to proclaim October 2009 as National Information Literacy Awareness Month. In that proclamation, President Obama stated:

Rather than merely possessing data, we must also learn the skills necessary to acquire, collate, and evaluate information for any situation... National Information Literacy Month highlights the need for all Americans to be adept in the skills necessary to effectively navigate the Information Age (Obama, 2009).

The information literacy-related competencies that many business and educational organizations state are necessary for readiness for the workforce and success in the workplace are:

- $21^{\text {st }}$ century literacy, defined as "the set of abilities and skills where aural, visual and digital literacy overlap. These include the ability to understand the power of images and sounds, to recognize and use that power, to manipulate and transform digital media, to distribute them pervasively, and to easily adapt them to new forms" (NMC, 2005)

- The ability to "use the research process to describe, summarize and synthesize information" (Achieve, 2008)

- Digital media literacy (Johnson, Smith, \& Stone, 2010, p. 5; Trilling \& Fadel, 2009, p. 65) defined as the use of "a variety of media and formats to evaluate, create and distribute information" (Achieve, 2008)

- Critical thinking, problem solving, and analytical reasoning skills (Hart, 2009; Trilling \& Fadel, 2009; Achieve, 2008; Lippman, Atienza, Rivers, \& Keith, 2008; The Conference Board, 2006; Klusek \& Bornstein, 2006)
- Lifelong learning and self direction (Lloyd, 2010; Lippman, et al., 2008; The Conference Board, 2006; Goad, 2002)

- Effective communication skills, orally and in writing; teamwork and collaboration (Hart, 2009; Trilling \& Fadel, 2009; Achieve, 2008; Hepworth \& Smith, 2008; Lippman, et al., 2008; The Conference Board, 2006; Klusek \& Bornstein, 2006; Peter D. Hart Research, 2005)

- Ability to locate, organize, and assess the credibility of information (Johnson, et al., 2010; Hart, 2009; Trilling \& Fadel, 2009)

- Information and communication technology (ICT) literacy (Trilling \& Fadel, 2009; The Conference Board, 2006)

- Judgment in sifting for relevant information among overwhelming amounts (Hepworth \& Smith, 2008)

- Social skills, including the ability to listen well (Hepworth \& Smith, 2008)

- The ability to formulate precise, accurate questions (Hepworth \& Smith, 2008)

\section{How Information Literacy Differs in Work and Educational Settings}

There is evidence that the information needs and information-seeking behaviors of those in the workforce are different than those of students (Lloyd, 2010; O'Farrill, 2010; Lloyd, 2008; Kirton $\&$ Barham, 2005). A corporate executive observed that the skills of the bright, motivated recent graduates his company hired became obsolete within two years. His interest in the reason for this eventually resulted in a donation for an endowed chair in information literacy for Purdue University (Schenke, 2005). In school, teachers assign projects, papers, or presentations during courses that must be completed within a specified time period. In the workplace, tasks and problems tend to be complex, messy, and openended. They can be difficult to analyze. They may employ different approaches to information seeking and use that go beyond the mastery of information-seeking skills to knowing "ways of thinking and seeing, and of crafting narrative" (Johnson, et al., 2010). In the workplace, tasks are context-specific, not generic. In that setting, 
information literacy focuses less on identifying information needs because problems are often very specific and assigned to an employee to resolve (Hepworth \& Smith, 2008). Workforce information literacy can be described as a sociocultural practice that informs learning in the workplace and is informed by it. It is a catalyst for learning (Lloyd, 2010). Social aspects are involved because people learn together and human relationships have a key role in development of information literacy in the workplace (O'Farrill, 2010; Crawford \& Irving, 2009; Somerville \& Howard, 2008). Even within the workplace, information literacy needs differ. Smith found that senior staff engaged in different information literacy activities than other staff. They used more primary sources, such as internally-generated information, than secondary sources that are important in academic work. Networking was a productive way for them to gather information. Information literacy skills that were necessary were time management, social networking, and organizing internal information such as emails (Hepworth \& Smith, 2008).

\section{Barriers to Information Literacy in Workplace}

Since information literacy in the workplace is a competency necessary for success, it is important to understand what the barriers are to making it a part of the culture and practices in organizations. One barrier is that $21^{\text {st }}$ century literacies are not well understood or sufficiently researched. Although the term, information literacy, was coined in 1974 (Zurkowski, 1974) and published reports on its importance for the workforce first appeared in 1989 (Presidential Committee, 1989), it is only in recent years that industry and researchers have begun to articulate a rationale for this emphasis. The research on workforce information literacy tends to focus on the training, service, and administrative sectors. There is little data on information literacy in jobs that do not require university degrees. The literature that exists focuses on using skills; the transfer of information literacy skills from education to the workplace; use of information in the workplace; and information-seeking behavior (Lloyd, 2010).
Therefore, many institutions lack sufficient data or incentive to change (NMC, 2005).

The question of who should assume the responsibility for teaching information literacy as applied to the workplace is unresolved. Most employers surveyed thought that K-12 schools, 4year colleges and universities, or the employees themselves were responsible (Casner-Lotto \& Silvert, 2008). Employers indicated that students would be better prepared for success if they had the skills to research questions in their field and to develop evidence-based analyses (Hart, 2009). They provided remedial training programs because of deficiencies in the skills they expected new hires to have, but the majority found these programs to be only moderately or somewhat successful (Casner-Lotto, 2009). Employers said that one-on-one coaching and mentoring were the most effective methods to improve employees' skills in these areas. Managers believed it was easier to develop these skills in students than in experienced workers (AMA, 2010, p. 6). However, there is some concern about what students who graduate from college know about the information resources available to them (Simon, 2009).

Lastly, college training in digital literacy skills is rare, although it is one of the critical challenges identified for 2010 (Johnson, et al., 2010).

\section{Recommendations for Organizational Practice}

Some of the reports discussed in this paper included recommendations for ways to increase information literacy in the workforce. This effort must be sustained and promoted by many stakeholders who are in close coordination. Those recommendations include:

- Raise awareness of information literacy as an interdisciplinary field of study and practice (NMC, 2005)

- Develop strategies for teaching and assessing workplace information literacy (NMC, 2005)

- Establish journals and clearinghouses to disseminate new models and research (NMC, 2005)

Education Libraries, Volume 34, Number 2, Winter 2011 
- Include media literacy in teacher training programs (European Parliament Committee, 2008); provide professional development opportunities on information literacy topics for teachers (NMC, 2005)

- Develop recognition programs that will help to publicize innovation and models

- Develop scalable, affordable solutions so that schools have access to new technologies (NMC, 2005)

- Provide professionally developed curricula and training (Rotherham \& Willingham, 2009)

- Work together as a community by engaging stakeholders in information literacy, involving them in disseminating models and ideas, and promoting networking (Crawford \& Irving, 2009; NMC, 2005; Oman, 2001)

- Emphasize skills such as critical thinking and effective writing and speaking in high school and college (The Conference Board, 2006)

- Ensure that corporate librarians and information specialists have the responsibility for ongoing professional development and training on information literacy in their organizations (Klusek \& Bornstein (2006)

- Establish explicit policies about information literacy expectations; conduct organizational skills audits (Crawford \& Irving, 2009). This is an example of a workplace policy that incorporates information literacy well:

"Organizations must demonstrate that education, training, and access to learning and library resources are available on an equitable and flexible basis to all staff, including, part time, community, evening and night shift workers and those working in remote locations" (Department of Health, 2001).

\section{Recommendations for Research}

Since information literacy and the workforce is a relatively new area of interest, there is much that needs to be studied to inform policy and practice.
The reports included in this review included the following recommendations for topics for research:

- Develop theory and models related to workforce information literacy (Lloyd, 2010; O’Farrill, 2010; NMC, 2005)

- Explore the meaning of workplace information literacy (O'Farrill, 2010)

- Develop a better understanding of the relationship between information literacy in the formal educational process and the workplace (O’Farrill, 2010; Lloyd, 2003)

- Determine the viability of workplace information literacy training programs (Crawford \& Irving, 2009)

- Explore the application of emerging technologies in achieving key institutional goals (Johnson, et al., 2010)

- Develop an understanding of the information practices of workers whose positions do not require a university education (Veinot, 2007)

\section{Conclusion}

This paper reviewed publications about information literacy and the workplace. Those publications were about three topics: the importance of information literacy for the workforce; how information literacy differs in work and educational settings; and barriers to information literacy in the workplace. Based on what is known from existing research, there are steps that can be taken to increase information literacy for employees. This will benefit the companies in which they work. There is a need for research on many aspects of workforce information literacy.

\section{References}

Achieve. (2008). Out of many, one: Toward rigorous common core standards from the ground up. Retrieved from http://www.achieve.org/files/CommonCore . $\mathrm{pdf}$

American Management Association. (2010). AMA 2010 critical skills survey. Retrieved from http://www.p21.org/documents/Critical\%2 
0Skills\%20Survey\%20Executive\%20Sum mary.pdf

Andretta, S. (Ed). (2007). Change and challenge: Information literacy for the 21st century. Adelaide: Auslib Press.

ACRL. (1989). Presidential Committee on Information Literacy: Final report.

Retrieved from

http://www.ala.org/ala/mgrps/divs/acrl/pub lications/whitepapers/presidential.cfm.

ACRL. (2000). Information literacy competency standards for higher education. Retrieved from

http://www.ala.org/ala/mgrps/divs/acrl/stan dards/standards.pdf

Casner-Lotto, J.,Rosenblum, E., \& Wright, M. (2009). The ill-prepared U.S. workforce: Exploring the challenges of employerprovided workforce readiness training. New York: The Conference Board, Inc. Retrieved from http://www.conferenceboard.org/publications/publicationdetail.cf m?publicationid $=1676$

Cavalieri J. (2009). Curriculum integration within the context of veterinary education. Journal of Veterinary Medical Education, 36, 388-396.

Cheuk, B. (2008). Delivering business value through information literacy in the workplace. Libri, 58, 137-43.

The Conference Board, Inc., the Partnership for 21st Skills, Corporate Voices for Working Families, and the Society for Human Resource Management. (2006). Are they really ready to work? Employers' perspectives on the basic knowledge and applied skills of new entrants to the $21^{\text {st }}$ century U.S. workforce. Retrieved from http://www.21stcenturyskills.org/document S/FINAL REPORT PDF09-29-06.pdf.

Crawford, J. \& Irving, C. (2009). Information literacy in the workplace: A qualitative exploratory study. Journal of Librarianship and Information Science, 41, 29-38.

Department of Health. (2001). Working togetherLearning together: A framework for lifelong learning for the NHS. London:
Department of Health. Retrieved from http://www.dh.gov.uk/prod_consum_dh/gr oups/dh_digitalassets/@dh/@en/document s/digitalasset/dh_4058896.pdf

Gardner, D. P. (Ed.). (2000). Learning at work: Tennessee profiles in workplace adult basic education. Center for Literacy Studies, The University of

Tennessee/Knoxville. Retrieved from http://www.cls.utk.edu/pdf/learning at wo rk.pdf

Garner, S.D. (2006). High-level colloquium on information literacy and lifelong learning, Bibliotheca Alexandrina, Alexandria, Egypt, November 6-9, 2005: Report of a meeting. Retrieved from https://docs.google.com/fileview?id=0B3S NEP9j56rIZGY3ODM4MDQtMGNiNS00 OTcyLTk0YmEtYjI0ODI1ZmU3ZGQ1\& $\mathrm{hl}=\mathrm{en}$

Gibson, C. (2004). Information literacy develops globally: The role of the National Forum on Information Literacy. Knowledge Quest, 34(4), 16-18.

Goad, T. W. (2002). Information literacy and workplace performance. Westport, CT: Quorum Books.

Hart Research Associates. (2009). Raising the bar: Employers' views on college learning in the wake of the economic downturn.

Retrieved from http://www.aacu.org/leap/documents/2009 EmployerSurvey.pdf

Hepworth, M., \& Smith, M. (2008). Workplace information literacy for administrative staff in higher education. Australian Library Journal, 57, 212-36.

Johnson, L., Levine, A., Smith, R., \& Stone, S. (2010). The 2010 Horizon Report. Austin, TX: The New Media Consortium. Retrieved from http://wp.nmc.org/horizon2010/

Kirton J., \& Barham, L. (2005). Information literacy in the workplace. Australian Library Journal, 54. Retrieved from http://alia.org.au/publishing/alj/54.4/full.te $\mathrm{xt} /$ kirton.barham.html 
Klusek, L. \& Bornstein, J. (2006). Information literacy skills for business careers: Matching skills to the workplace. Journal of Business \& Finance Librarianship, 11, 3-21.

Lippman, L., Atienza, A., Rivers, A., \& Keith, J. (2008). A developmental perspective on college \& workplace readiness.

Washington, DC: Child Trends. Retrieved from

http://www.childtrends.org/Files/Child_Tr ends-

2008_09_15_FR_ReadinessReport.pdf

Lloyd, A. (2003). The meta-competency of the knowledge economy. Journal of

Librarianship and

Information Science, 35, 87-92.

Lloyd, A., \& Williamson, K. (2008). Towards an understanding of information literacy in context: Implications for research. Journal of Librarianship and Information Science, 40; 3-12. doi: 10.1177/0961000607086616

Lloyd, A. (2010). Information literacy landscapes: Information literacy in education, workplace and everyday contexts. Oxford: Chandos Publishing.

NMC: The New Media Consortium. (2005). A global imperative: The report of the 21st Century Literacy Summit. Retrieved from http://www.nmc.org/pdf/Global_Imperativ e.pdf

Obama, B. (2009). National Information Literacy Awareness Month, 2009. Retrieved from http://www.whitehouse.gov/the press_offi ce/Presidential-Proclamation-NationalInformation-Literacy-Awareness-Month/

O'Farrill, R. T. (2010). Information literacy and knowledge management at work:

Conceptions of effective information use at NHS24. Journal of Documentation 66, 706-733. doi: $10.1108 / 00220411011066808$

Oman, J. N. (2001). Information literacy in the workplace. Information Outlook, 5. Retrieved from http://www.sla.org/content/Shop/Informati on/infoonline/2001/jun01/oman.cfm
Partnership for 21st Century Skills. (2009). Framework for $21^{\text {st }}$ century learning. Retrieved from http://www.p21.org/documents/P21_Frame work.pdf

Perrault, A. (2007). American competitiveness in the Internet age: Information Literacy Summit, October 16, 2006, Washington, DC. Retrieved from https://docs.google.com/fileview?id=0B3S NEP9j56rIODA2MTI3MDktOTE4My00 MjkwLWJhMTgtOWZkYjI4MGQzZTVj $\& \mathrm{hl}=\mathrm{en} \& \mathrm{pli}=1$.

Peter D. Hart Research Associates/Public Opinion Strategies. (2005). Rising to the challenge: Are high school graduates prepared for college and work? Study of recent high school graduates, college instructors, and employers. Retrieved from http://www.achieve.org/node/548.

Report on media literacy in a digital world (2008/2129(INI). (2008). European Parliament Committee on Culture and Education. Retrieved from http://www.europarl.europa.eu/sides/getDo c.do?pubRef $=-$ //EP//NONSGML+REPORT+A6-2008 $-0461+0+\mathrm{DOC}+\mathrm{PDF}+\mathrm{V} 0 / / \mathrm{EN}$

Rotherham, A. J., \& Willingham, D. (2009). 21st century skills: The challenges ahead. Educational Leadership, 67, 16-21. Retrieved from http://www.ascd.org/publications/educatio nal-leadership/sept09/vol67/num01/21stCentury-Skills@-The-ChallengesAhead.aspx

Schenke, J. (2005). Purdue opens new chapter in national information literacy. Purdue University News, Sept. 30. Retrieved from http://news.uns.purdue.edu/html3month/20 05/050930.Celebrate.library.html

Simon, C. (2009). Graduate business students and business information literacy: A novel approach. Journal of Business and Finance Librarianship, 14, 248-67.

Thompson, S. (2003). Information literacy meeting of experts, Prague, the Czech Republic, September 20-23, 2003: Report 
of a meeting. Retrieved from

https://docs.google.com/fileview?id=0B3S NEP9j56rIMjM4OGJiNWItM2E4Ni00Yjc 0LWJjYTctZDMxZTVlOGYyMDAy\&hl= en

Somerville, M. M., \& Howard, Z. (2008). Systems thinking: An approach for advancing workplace information literacy. Australian Library Journal, 57, 257-73.

Trilling, B., \& Fadel, C. (2009). 21st century skills: Learning for life in our times. San Francisco: Jossey-Bass.

Veinot, T. (2007). The eyes of the power company: Workplace information practices of a vault inspector. Library Quarterly, 77, 157-79.

Weiner, S., \& Jackman, L. (2010). Information literacy beyond the library: The National Forum on Information Literacy. College \& Undergraduate Libraries, 17, 114-20. doi:10.1080/10691310903584734

Weiner, S. (2011). How information literacy becomes policy: An analysis using the
Multiple Streams Framework. Accepted for publication in Library Trends.

Zhang, X., Majid, S., \& Foo, S. (2010).

Environmental scanning: An application of information literacy skills at the workplace. Journal of Information Science, 36, 719-32.

Zurkowski, P. G. (1974). The information service environment: Relationships and priorities. Washington, DC: National Commission on Library and Information Science. Retrieved from http://www.eric.ed.gov/PDFS/ED100391.p $\underline{\mathrm{df}}$

Sharon Weiner, EdD, MLS

Professor and W. Wayne Booker Chair in Information Literacy

Purdue University 504 West State Street West Lafayette, IN 47906 765-496-3128

sweiner@purdue.edu 